
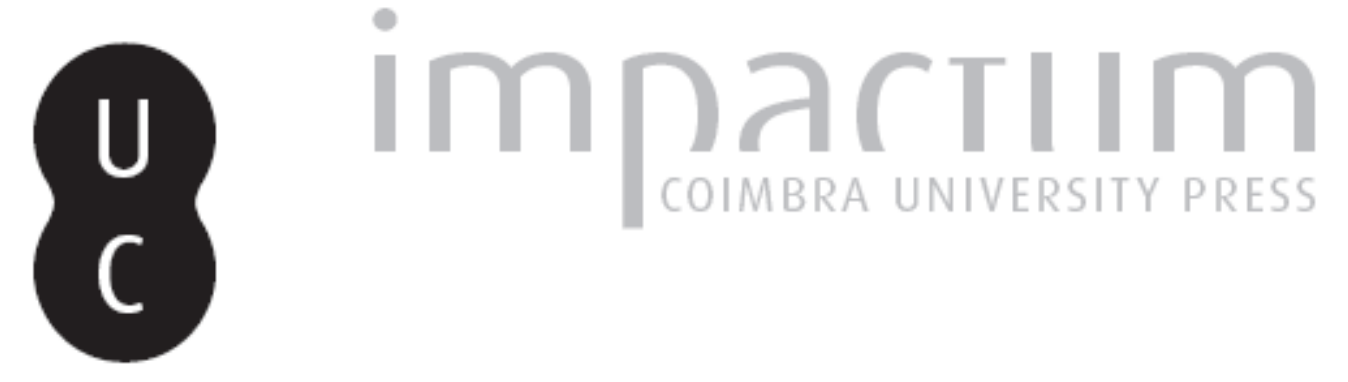

\title{
Alguns vulcões da Ilha de S. Miguel, de Victor Hugo Forjaz
}

\section{Autor(es): Rebelo, Fernando}

Publicado por: Associação Portuguesa de Riscos, Prevenção e Segurança

URL persistente:

URI:http://hdl.handle.net/10316.2/40139

DOI:

DOI:https://doi.org/10.14195/1647-7723_5_8

Accessed : $\quad$ 26-Apr-2023 09:50:48

A navegação consulta e descarregamento dos títulos inseridos nas Bibliotecas Digitais UC Digitalis, UC Pombalina e UC Impactum, pressupõem a aceitação plena e sem reservas dos Termos e Condições de Uso destas Bibliotecas Digitais, disponíveis em https://digitalis.uc.pt/pt-pt/termos.

Conforme exposto nos referidos Termos e Condições de Uso, o descarregamento de títulos de acesso restrito requer uma licença válida de autorização devendo o utilizador aceder ao(s) documento(s) a partir de um endereço de IP da instituição detentora da supramencionada licença.

Ao utilizador é apenas permitido o descarregamento para uso pessoal, pelo que o emprego do(s) título(s) descarregado(s) para outro fim, designadamente comercial, carece de autorização do respetivo autor ou editor da obra.

Na medida em que todas as obras da UC Digitalis se encontram protegidas pelo Código do Direito de Autor e Direitos Conexos e demais legislação aplicável, toda a cópia, parcial ou total, deste documento, nos casos em que é legalmente admitida, deverá conter ou fazer-se acompanhar por este aviso.

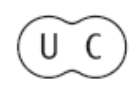




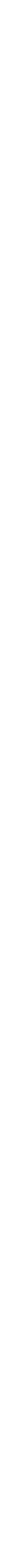


4. A erupção vulcânica de 1995 na Ilha do Fogo, Cabo Verde (Lisboa, Instituto de Investigação Científica Tropical, 1997, 421 p.) é o título de um livro que analisa a manifestação de uma crise de vulcanismo com um pormenor verdadeiramente excepcional. Trata-se da publicação das comunicações apresentadas num Simpósio Internacional efectuado em Lisboa, na Fundação Calouste Gulbenkian, de 23 a 25 de Setembro de 1996 e que permitiu dar uma visão científica muito profunda de tudo o que se relacionou com aquela erupção, desde os sismos que a antecederam ou que lhe foram simultâneos até às consequências ambientais que dela advieram.

Oito comunicações relacionam-se com o "enquadramento geotectónico". Duas delas referem-se concretamente aos sismos verificados, enquanto as outras dão as necessárias bases explicativas para a crise. A "caracterização da erupção"é dada por nove comunicações, uma das quais com aspectos descritivos, referindo-se à sua cronologia, as outras aprofundando diversos pormenores científicos das suas lavas ou simples incrustações. Finalmente, os "impactos da erupção" permitiram a diversos autores, em treze comunicações, tratarem de assuntos tão diversos como o controle das escoadas, a análise dos diferentes riscos, inclusivamente dos riscos para a saúde pública, as influências das erupções nas temperaturas do ar, os impactos sócio-económicos, a protecção civil, etc.

Como primeiros Autores das 30 comunicações agora publicadas encontram-se nomes como os de L. MATIAS, S. HELENO DA SILVA (duas), J. L. PEREIRA, A. BRUM DA SILVEIRA (duas), J. L. GASPAR, J. OSÓRIO, F. C. TORRES (duas), N. WALLENSTEIN, J. MADEIRA, L. C. SILVA, J.M. MUNHÁ, M. O. FIGUEIREDO (três), F. LE GUERN (duas), F. LAGOSCOSTA,L. QUENTAL, H.TAZZIEF, T. FERREIRA, E. CORREIA, L. A. BUGALHO, R. L. BARBER, J. CORREIA e F. MONTEIRO. Umdos nomes que aparece ligado a mais comunicações (sete)é o do geólogo caboverdiano A. MOTA GOMES, que assina duas delas como primeiro Autor.

Deste volume fazem parte ainda os discursos da sessão de abertura do Simpósio, as homenagens prestadas a Orlando Ribeiro (não esqueçamos o seu trabalho intitulado A Ilha do Fogo e as suas erupções, Lisboa, 1954, com uma segunda edição em 1960), a Torre de Assunção e a Frederico Machado, bem como os resumos de três conferências solicitadas, respectivamente, a António Ribeiro, J. E. Guest e A. Hirn. O livro termina com 12 interessantes fotografias a cores de aspectos diversos da erupção de 1995.

\section{Alguns vulcōes da Itha de S. Miguel, de Victor Hugo Forjaz*}

\section{Fernando Rebelo}

Editado em Ponta Delgada, em 1997, pelo Observatório Vulcanológico e Geotérmico dos Açores, este livro começa por dar ao leitor alguma informação histórica e geográfica sobre S. Miguel; destaquemos que, do ponto de vista geomorfológico, divide a ilha em 7 "conjuntos paisagísticos", a saber, Maciço das Sete Cidades, Plataforma dos Picos, Maciço da Lagoa do Fogo, Achada Congro-Furnas, Maciço das Furnas, Achada dos Boiões (Graminhais) e Maciço da Povoação-Nordeste.

O "historial geológico" dailha de S. Miguel começa por ser apresentado através daquilo a que o Autor chama "estudos geológicos clássicos". Gaspar Frutuoso (1522-1591) aparece como "o primeiro dos nossos vulcanólogos" na medida em que, sendo bom observadore contemporâneo de erupções, deixou, nas Saudades da Terra, escritos importantes para a sua época sobre a geologia da ilha. Vários Autores do século XIX são, igualmente, referidos, alguns dos quais escreveram sobre as águas minerais. Referências breves a diversos trabalhos da primeira metade do século XX, um

VICTOR HUGO FORJAZ, Alguns Vulcōes da Il ha de S. Miguel, l Parte, Ponta Delgada, Observatório Vulcanológico e Geotérmico dos Açores, 1997,160 p. certo destaque para os de G. Zbyszewski e de F. Machado já de meados dos anos 50 e curtas referências a numerosos trabalhos publicados desde 1970 completam esse "historial".

O maior capítulo deste livro é o que se intitula "Vulcanoestratigrafia". Inicia-se com a legenda da carta geológica de S. Miguel, publicada em 1959, e com a da carta vulcanológica de 1976, ambas a 1:50000, culminando com a vulcanoestratigrafia que o Autor propõe para uma carta vulcanológica a 1:25000. A partir daí, a explicação da estratigrafia é feita pormenorizadamente para cada uma das áreas que correspondem a diferentes fases de formação da ilha - área do Nordeste (a mais antiga, do Pliocénico e Plistocénico superior), área da Povoação, área das Furnas, área das Sete Cidades, área do Fogo, área dos Picos e erupções históricas. Fica, portanto, claramente expressa a formação da ilha a partir de duas ilhas "a ilha de S. Miguel (somatório dos territórios do Nordeste com os da Povoação e os das Furnas) separada por um longo canal (tal como hoje Faial e S. Jorge) da ilha das Sete Cidades" (p. 116).

É precisamente na parte final do livro, e antes de falar nos recursos naturais, que o Autor nos faz 
pensar em riscos. Primeiro, são as descrições possíveis de muitas erupções históricas, como manifestações de crise vividas (e por vezes muito sofridas) pelos micaelenses, depois é o capítulo sobre "tectónica e sismicidade". Embora não se fale expressamente em riscos, a verdade é que eles saltam à vista quando se lê com atenção este capítulo - a sismicidade é grande em tempos históricos muito recentes e as falhas activas estão bem localizadas.

Alguns vulcões da ilha de S. Miguel é ainda um livro acessível no seu texto e ricamente ilustrado com numerosas (e lindíssimas) fotografias a cores, com reproduções de estampas antigas e bastantes figuras, algumas também a cores. 